\title{
Development of Mathematics Learning Process by Using Flipped Classroom Integrated by STEAM Education in Senior High School
}

\author{
Sutama*, Harun Joko Prayitno, Naufal Ishartono, Diana Purwita Sari \\ Faculty of Education and Teacher Training, Universitas Muhammadiyah Surakarta (UMS), Surakarta, Indonesia
}

Received January 6, 2020; Revised May 20, 2020; Accepted May 28, 2020

Copyright (C2020 by authors, all rights reserved. Authors agree that this article remains permanently open access under the terms of the Creative Commons Attribution License 4.0 International License

\begin{abstract}
Purpose: There are two purposes of this study. 1) Describe the developing process of mathematics learning process by using flipped classroom integrated by five disciplines, namely science, technology, engineering, art, and mathematics (STEAM). 2) Test the effectiveness of mathematics learning with flipped classroom-oriented STEAM in high school. Methodology: This research is research and development $(\mathrm{R} \& \mathrm{D})$ with the ADDIE model, which comprises five stages, i.e. analysis, design, development, implementation, and evaluation. Data collection techniques were done by observation, walkthrough, and tests. The research was conducted in SMA Negeri 1 Gemolong on 2019/2020 academic year. Data collection techniques were done by observation, walkthrough, and tests. Results: The results showed that 1 ) The process of learning mathematics with flipped classroom-oriented STEAM, namely (a) Before face-to-face stage in class, students were asked to learn independently by watching learning videos on the internet; (b) Students were divided into several heterogeneous groups and given problems and projects in each group (groups of 4-6 students); (c) Each group was asked to solve a problem by integrating five disciplines (STEAM); (d) The teacher facilitated and monitored students in designing the project; (e) Students completed projects outside the classroom; (f) Students presented project results in class; and (g) In the end of a lesson, students were given a quiz or a short test. 2) Mathematics learning through flipped classroom-oriented STEAM was effective in terms of material mastery. Applications/Originality/Value: The findings of this research give overviews regarding to the implementation of flipped classroom integrated by STEAM learning which increases students' understanding.
\end{abstract}

Keywords Flipped Classroom, STEAM Education, ADDIE, Research and Development

\section{Introduction}

Nowadays, Indonesia is facing the industrial revolution 4.0 era. To face this era, it requires education to integrate knowledge skills, skills and attitudes, and mastery of information and communication technology (Serdyukov, 2017). In education, the government has pursued the development of students' ability in mastering technology to get a nation generation that is ready and reliable to face the industrial revolution 4.0 era. The 2013 curriculum renewal by the government requires students to live as individuals and citizens who are productive, creative, innovative, effective, and able to contribute to society, nation and state, and world civilization (Permendikbud No. 70, 2013).

Government regulation (Permendikbud) No. 22 of 2016 explains that the learning process in the education unit was held interactively, inspirational, fun, challenging, motivating students to take part actively, and provided sufficient space for the initiative, creativity, independence, following the talents, interests, and physical and psychological development of students. Educational theories have been developed so that various learning models have appeared to help improve the quality of learning. The educational change began to develop slowly, and technological developments over the past decade offer new educational models and unique ways to improve the quality of learning (Kinshuk, Chen, Cheng, Chew, 2016).

Based on the results of the pre-survey in SMA Negeri 1 Gemolong, mathematics learning is still transmissive. The teacher is the only learning source in learning mathematics. Students passively absorb or accept the knowledge given by the teacher. This is because students could not be directed as subjects in learning. It leads student only being 
able to achieve a cognitive understanding of level 1 (remembering) and level 2 (understanding), and yet reach cognitive level 3 (applying), level 4 (analyzing), level 5 (evaluating), and level 6 (creating) based on the Revised Bloom Taxonomy (Anderson \& Krathwohl, 2001). This result must be an evaluation material for teachers. Teachers can improve the quality of learning by optimizing resources such as information and communication technology that is developing rapidly (Darling-Hammond, Flook, Cook-Harvey, Barron, \& Osher, 2019).

The 21st-century learning should apply to face challenges and demands of real life, including the emergence of the ability to cooperate, the ability to solve problems, the ability to self-mastery, the ability to think critically, master the technology, and be able to process information and communicate effectively. This is because of the learning objectives to make students ready to compete (Jan, 2017). Teachers required having the ability to explore students by persuading students actively involved in creative, interesting, innovative, and fun learning, so students have the desire to participate and play in an active role (Bregmark \& Westman, 2018).

Flipped classroom learning is one of the learning strategies that have the characteristics of being able to explore students actively involved in learning. The flipped classroom is a learning innovation where students learning outside the classroom or at home independently, then conduct discussions or active learning in the class (Wang \& Zhu, 2019). Flipped classroom strategy gives what is generally done in class and what it usually does as homework and then reversed or exchanged (Aycicek \& Yelken, 2018). Previously students came to class to listen to the teacher's explanation, and then they returned to work on the practice questions. The learning process that happens now is that students read the material, see the learning video before they come to class, and when they arrive at the class, they discuss, exchanging knowledge, solving problems with the help of other students and teachers.

The flipped classroom learning strategy is very suitable to be implemented with a learning approach that facilitates students to explore solving problems scientifically and based on technology. This is because learning in the 21st century requires a learning approach that can create ideas based on science and technology through thinking and exploring activities in solving problems based on five integrated disciplines (Connor, Karmokar, \& Whittington, 2015). The five disciplines referred to science, technology, engineering, art, and mathematics (STEAM). STEAM was born after it defined the STEM (science, technology, engineering, and mathematics) concept. STEAM was born and emerged after the addition of the art discipline integrated with STEM.

Learning with the STEAM approach is a breakthrough in learning mathematics. The 2013 curriculum, which integrates mathematics learning thematically, will be very suitable to be integrated with STEAM learning. In science, it requires students to use the scientific method approach in solving a problem in everyday life. In technology, students will collaborate in using technology, both to process data and convey the information they get. In engineering, students will collaborate their findings to create a product or can also be interpreted to find the right solutions to a problem. In art students will create their products or findings, so the public can accept them or how they promote their findings. In mathematics, students will use a mathematical approach in processing their data to get the right solution to a problem.

Research related to the application of flipped classroom has been done by many researchers beforehand and provides good learning outcomes such as increased applicative and critical thinking of students (Wilson, Waghel, \& Dinkins, 2019) and students' learning ability (Zhu, Lian, \& Engström, 2019). Even in its development, many researchers are integrating flipped classrooms with today's technology such as integrating flipped classrooms with the Internet of Things (IoT) (Ali et al., 2017). From the results of previous studies, there are still few studies that try to integrate flipped classrooms with STEAM Education. So that the problems that arise are related to (1) how the process of developing flipped classroom integrated by STEAM Education in teaching mathematics, and (2) how effective the implementation of flipped classroom integrated by STEAM Education in teaching mathematics. Therefore, the purpose of this study is to (1) describe the process of developing flipped classroom integrated by STEAM Education in teaching mathematics, and (2) test the effectiveness of the application of flipped classroom integrated by STEAM Education in teaching mathematics

\section{Research Methods}

This research is research and development (R\&D) (Sutama, 2018: 196). The research was conducted in SMA Negeri 1 Gemolong on 2019/2020 academic year. The development strategy used in this research and development was ADDIE, which comprises five stages, i.e. analysis, design, development, implementation, and evaluation (Ishartono, Juniati, \& Lukito, 2016).

Data collection techniques were done by observation, walkthrough, and tests. Observations conducted to fulfill the needs of the analysis, which included needs analysis and curriculum analysis. Walkthroughs were done to test the feasibility of the developed product (product validation by experts). In the feasibility assessment, the researcher used a Likert scale with five scale scoring i.e.: very feasible (score 5), feasible (score 4), less feasible (score 3), not feasible (score 2), and very improper (score 1). The test used to test the effectiveness of the developed product. It illustrated the study implementation in detail in Figure 1. 


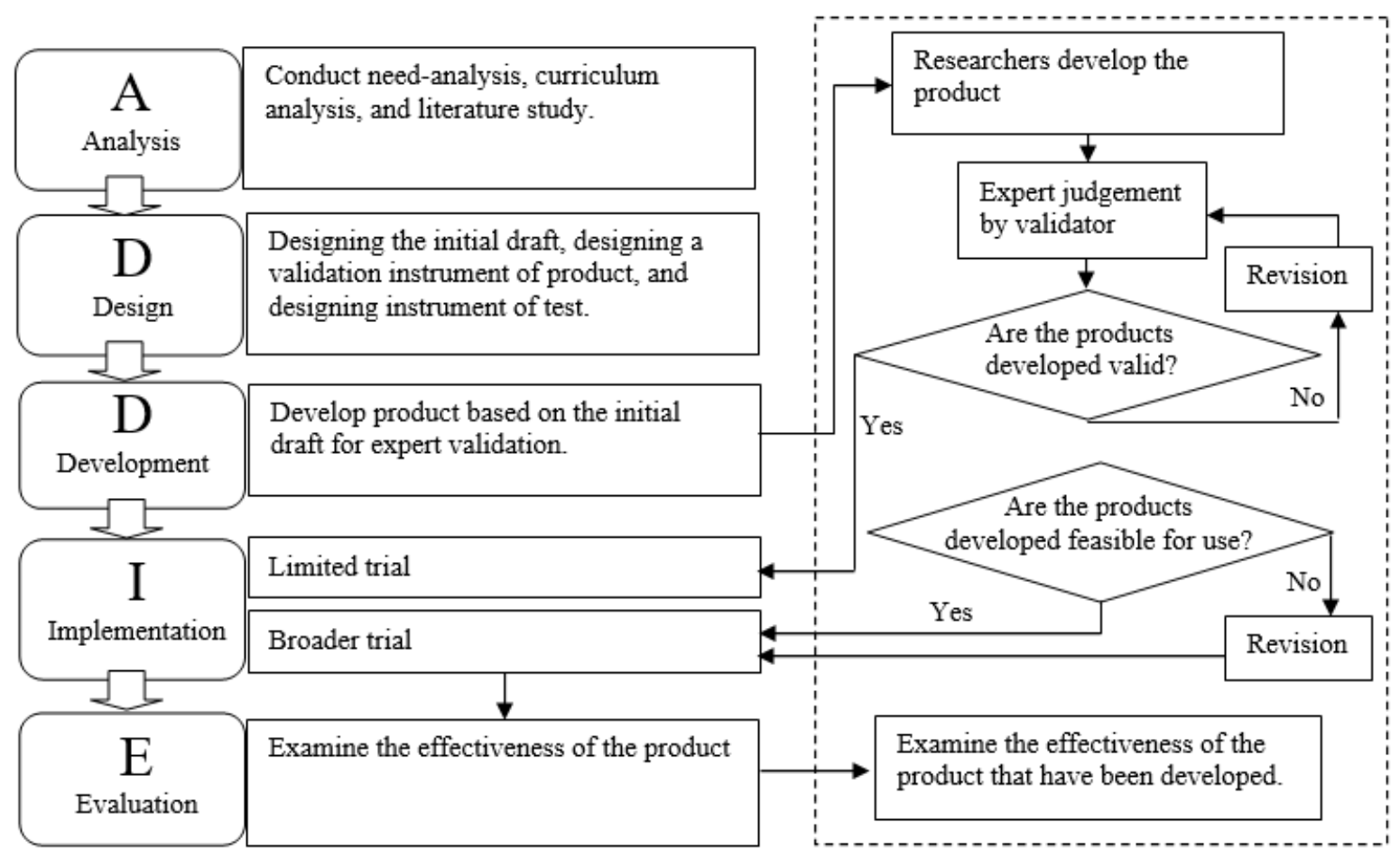

Figure 1. The implementation of research activities

\section{Research Result and Discussion}

The result of this development research was mathematics learning strategy through flipped classroom-oriented STEAM. Implementing flipped classroom learning with the STEAM approach became a necessity to develop higher-order thinking skills while developing creativity in learning mathematics. The development strategy for this research and development was ADDIE, which comprises five stages, i.e. analysis, design, development, implementation, and evaluation.

\section{Analysis}

The analysis activities in this research and development comprised needs analysis, curriculum analysis, and literature study. A needs analysis was the first step that should be done in research and development. In this activity, the researcher identified priority needs that needed to be fulfilled immediately. This because, through needs analysis, researchers could find a situation that should exist (what should be) and the actual situation in the field (what is) by looking at the gaps that occur. The researchers could provide alternative solutions to the problem through product development (Schipper, Goei, Vries, \& Veen, 2017). The results of the needs analysis study in the pre-survey activity showed that schools needed learning innovations that made students as the main subjects in learning. Researchers also conducted a curriculum analysis at this stage. This because the curriculum was an educational program provided by an educational provider that contained a lesson plan that would be given to lesson participants (students) in one educational period (Young, 2014). So, in product development, the curriculum that applied to schools must guide researchers.

A literature study was an important part that needs to be considered in research development. A literature study was a technique to find reference theories that relevant to the case or a problem found (Collins \& Stockton, 2018). At this stage, the researcher looked for literature which a guide in product development. It was conducted to make the product developed can overcome the existing problem.

\section{Design}

At this stage, the researcher prepares the initial draft of the product. This design was developed based on the results of analysis studies that had been carried out. The initial draft of the product being develops presented in Figure 2.

At the design stage, the researcher also designed the product validity instrument. The instrument has a substantial role in research. This is because an instrument was a tool that fulfills academic requirements, so it could be used as a tool to measure a measuring object or collect data about a variable (Taherdoost, 2016). It created the product assessment instrument in this research and development to test the validity and feasibility of the product and the product's effectiveness against mathematics learning. 
The Traditional Learning

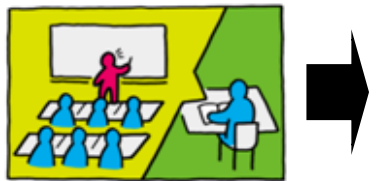

Teacher centered learning
The Traditional Learning

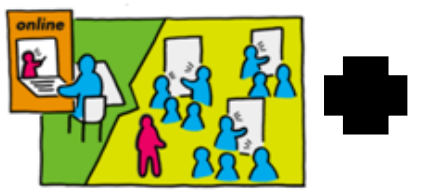

Students centered learning
STEAM Approach

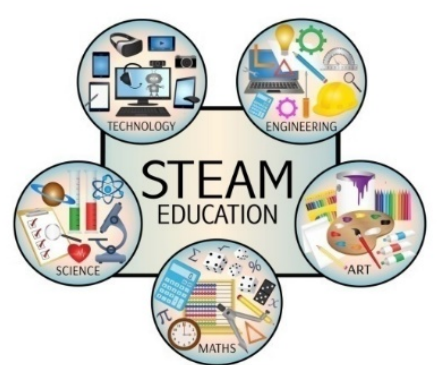

Figure 2. Designing the initial draft of flipped classroom oriented STEAM

\section{Development}

In the development stage, the researcher developed the initial draft design in a product form. Experts validated products that had been developed. At this stage, the walkthrough technique had an important role. The walkthrough was a way to test or validate a prototype or design conducted by experts in their field directly, so interactions formed which leaded to the improvement of prototypes or discussions (Klerk, Veldkamp, \& Eggen, 2018). The product validation includes supporting theory, the flipped classroom learning structure with the STEAM approach, and the desired learning objectives. 3 experts, who are experts in their fields conducted the product validation. The results of the expert assessment stated that it could use the product with minor revisions. The expert suggested the researcher added the item "the teacher facilitates and monitors students in designing projects in class". It aims to make the products made by students compatible with what is expected and can be completed immediately, so effective learning created. Effective learning is a learning process that is not only focused on the results achieved by students, but how an effective learning process can provide a good understanding, intelligence, perseverance, opportunity, and quality, and can provide behavioral change and apply it in their lives (Blazar \& Kraft, 2017). The results of the flipped classroom learning development with the STEAM approach are shown as follows.

1) Before face-to-face stage in class, students were asked to learn independently by watching learning videos on the internet;
2) Students were divided into several heterogeneous groups and given problems and projects in each group (groups of 4-6 students);

3) Each group was asked to solve a problem by integrating five disciplines (STEAM);

4) The teacher facilitated and monitored students in designing the project;

5) Students completed projects outside the classroom; and

6) Students presented project results in class.

\section{Implementation}

In this step, the researchers conducted a trial of the developed product. There were two trials in this research and development, namely limited trials and wider trials. The limited trial involved one class (7 groups). It limited the trial results to flipped classroom learning with the STEAM approach shown as follows.

\section{Science}

In science, it requires students to use the scientific method approach in solving a problem in everyday life. Scientific methods is a learning process that is designed so students can actively construct concepts, laws or principles through stages of observing (to identify or find a problem),formulates a problem, proposes or plans a hypothesis, collects data by various techniques, analyzing data, drawing conclusions and communicating concepts, laws or principles found (Yuniarti, Susanto, \& Irvan, 2018). One problem in a limited trial presented in Figure 3. 


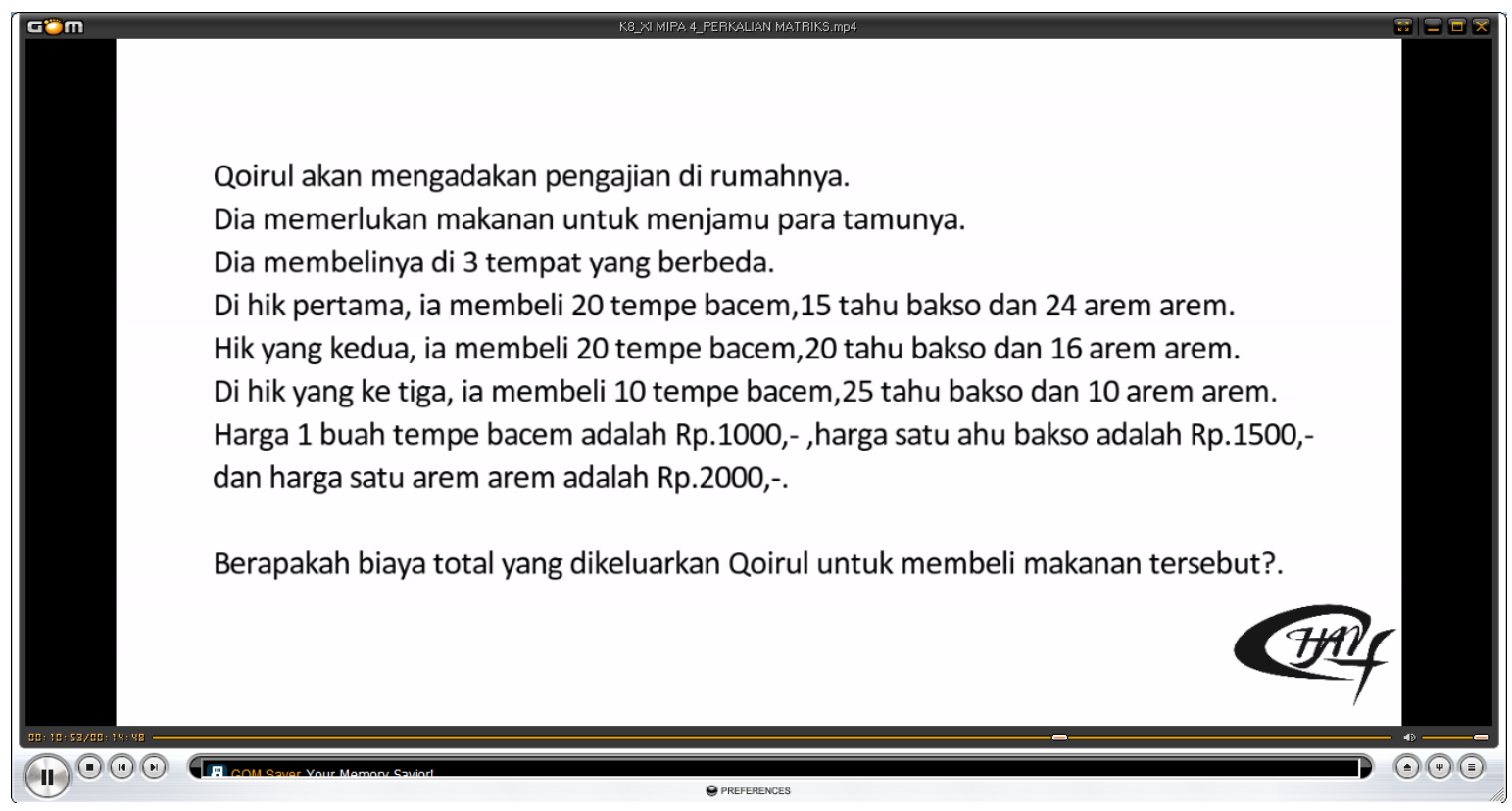

Figure 3. The problem must be solved by the STEAM approach

\section{Technology}

Technology has an essential role in learning. Li (2016) explained the role of technology in education could change conventional learning (teacher centered learning) into active learning (student centered learning) that made students the main subject. This because, through technology, students can find various sources of information related to the subject. Students can be more independent in completing projects given by the teacher with the role of technology in the classroom. A concrete manifestation of the role of technology in classroom learning is shown in Figure 4.

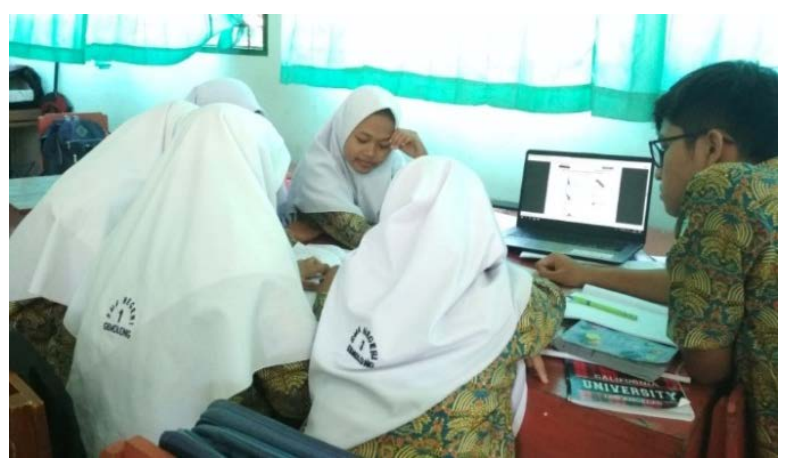

Figure 4. The role of technology when learning in the classroom

\section{Engineering}

In engineering, students will collaborate their findings to create a product or can also be interpreted to find the right solutions to a problem. The discovery of the right solution to a problem cannot be separated from the role of science and technology (Kelley \& Knowles, 2016). One problem can be solved by integrating various fields of science, so it is possible to produce several appropriate solutions (English, 2016). Students will compete to solve problems unusually (they have never done it before). Solving such problems makes students able to think critically, systematically, and logically. This is because a structured mindset formed in the individual, so students can be skilled in dealing with problems that must be resolved (Sutama, Anif, Prayitno, \& Sari, 2019).

\section{Art and Mathematics}

Relation of art and learning is creating a product or finding so the community can accept it or how they promote the findings, so the wider community knows about it (Ceylan \& Ozdilek, 2014). Students will compete to solve an existing problem by creating an interesting product, and other students can accept the results. In this discipline, we teach students to become teachers to their friends. Students will compete to make interesting videos to get the attention of their friends. This because the video is one of the social media forms that interested by students because of its attractive form (Coles, 2019).

In the mathematics discipline, students will use a mathematical approach in processing the data. Students will solve mathematical problems given by the teacher by integrating the four other disciplines, i.e.: science, technology, engineering, and art. The results of problem-solving based on meta disciplines that integrate STEAM shown in Figure 5. 


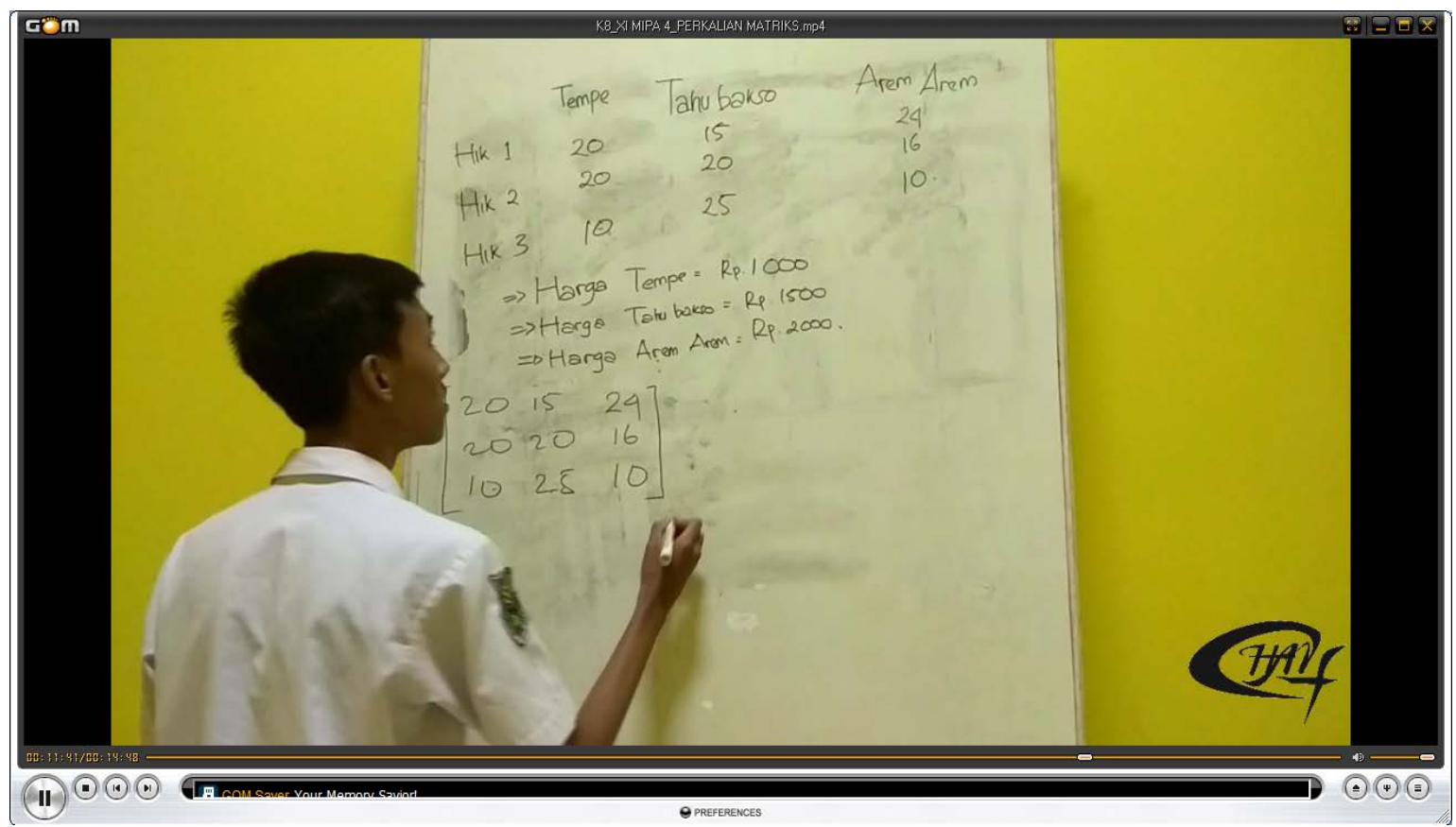

Figure 5. The results of the flipped classroom learning integration with the STEAM approach

Limited product trials have given good results. These results got based on student assessment, which stated that the product developed was suitable for learning. It shows the results of the product eligibility assessment in Figure 6.

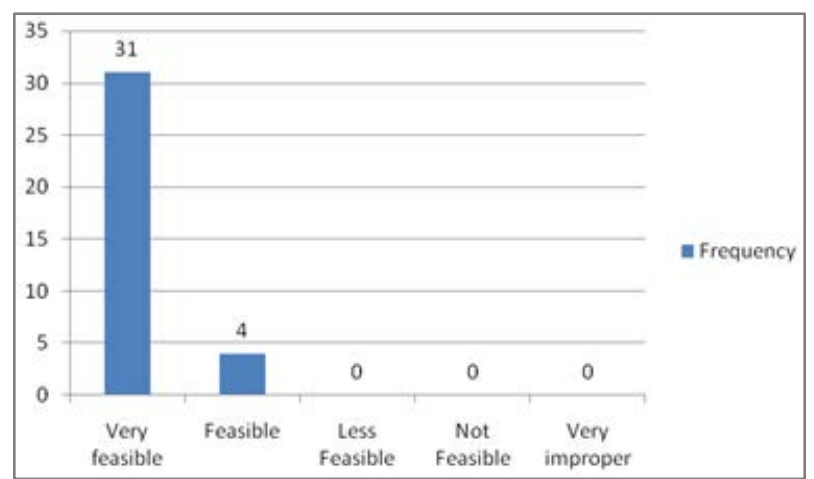

Figure 6. Student assessment of the product eligibility being develop.

Although the product gets a positive assessment by students, the researcher feels the need to conduct a learning evaluation with a quiz (short test). Researchers add the final step in flipped classroom learning with the STEAM approach, where the teacher gives a quiz at the end of the lesson. This evaluation activity aims to make students aware that the activities they are doing are not only games but also part of the learning process (Akiba, Murata, Howard, \& Wilkinson, 2019).

\section{Evaluation}

The results of the product effectiveness testing through the test instrument concluded that students who meet the minimum completeness criteria (more than 75) are over $75 \%$. I consider these results show that flipped classroom learning with the STEAM approach effective in learning mathematics. The details result of mathematics learning through flipped classroom learning with the STEAM approach shown in Figure 7.

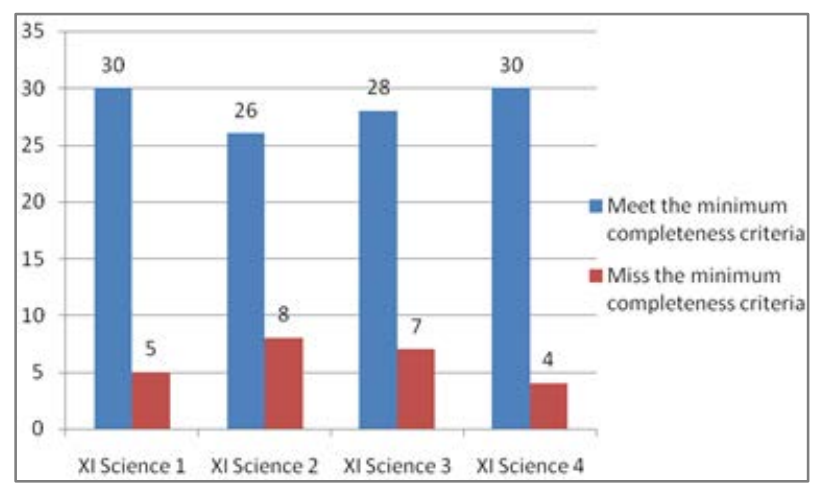

Figure 7. The results of mathematics learning through flipped classroom learning with the STEAM approach.

Flipped classroom learning with the STEAM approach can provide new opportunities for students to be directly involved in learning processes by producing a product that educates students to always think critical and innovative. Critical and innovative thinking is a component of resources that must be prepared to confront the industrial revolution 4.0 era (Morrar, Arman, \& Mousa, 2017). Because of this, to develop higher-order thinking skills while developing creativity, implementing flipped classroom learning with the STEAM approach becomes a necessity in learning mathematics.

\section{Conclusions}

Flipped classroom learning with the STEAM approach can provide new opportunities for students to be directly 
involved in learning processes by producing a product. So, it educates students to always think critical and innovative. The process of learning mathematics with flipped classroom-oriented STEAM, namely (1) Before face-to-face stage in class, students were asked to learn independently by watching learning videos on the internet; (2) Students were divided into several heterogeneous groups and given problems and projects in each group (groups of 4-6 students); (3) Each group was asked to solve a problem by integrating five disciplines (STEAM); (4) The teacher facilitated and monitored students in designing the project; (5) Students completed projects outside the classroom; (6) Students presented project results in class; and (7) In the end of a lesson, students were given a quiz or a short test. Mathematics learning with flipped classroom-oriented STEM is effective in terms of mastery learning. So, mathematics learning is workable or can be implemented.

\section{Acknowledgement}

We would like to thank various parties who have supported this research. Our gratitude goes to the Directorate of Research and Community Service, the Directorate of Research and Technology for strengthening research and development of the Ministry of Research, Technology, and Higher Education, who has help fund mono research fund through the Thesis Research Grant. Our gratitude goes to the Director of the Graduate School and the Chair of the UMS Research Institute and its staff, who have provided facilities and encouragement so we can conduct research. Our gratitude also goes to the head of the Education Office, the head and mathematics teacher of SMA Negeri 1 Gemolong, Sragen, Central Java, who has helped the research process, so it goes according to plan.

\section{REFERENCES}

[1] Akiba, M., Murata, A., Howard, C. C., \& Wilkinson, B. (2019). Lesson study design features for supporting collaborative teacher learning. Teaching and Teacher Education, 77, 352-365. doi:https://doi.org/10.1016/j.tate.2018.10.012

[2] Ali, M., Syed, H., Bilal, M., Razzaq, M. A., Khan, J., Idris, M., ... Kang, B. H. (2017). IoTFLiP: IoT-based Flip Learning Platform for Medical Education Maqbool. Digital Communications and Networks, 3(3), 188-194. https://doi.org/10.1016/j.dcan.2017.03.002

[3] Anderson, L. W., \& Krathwohl, D. R. (2001). A Taxonomy for Learning, Teaching, and Assessing: A Revision of Bloom's Taxonomy of Educational Objectives. New York: Longman.

[4] Aycicek, B., \& Yelken, T. Y. (2018). The effect of flipped classroom on students' classroom engagement in teaching english. International Journal of Instruction, 11, 385-398. doi: https://doi.org/10.12973/iji.2018.11226a

[5] Blazar, D., \& Kraft, M. A. (2017). Teacher and teaching effects on students' attitudes and behaviour. Educational Evaluation and Policy Analysis, 39, 146-170. doi: https://doi.org/10.3102/0162373716670260

[6] Bregmark, U., \& Westman, S. (2018). Student participation within teacher education: emphasising democratic values, engagement and learning for a future profession. Higher Education Research \& Development, 37, 1352-1365. doi: https://doi.org/10.1080/07294360.2018.1484708

[7] Ceylan, S., \& Odilek, Z. (2015). Improving a sample lesson plan for secondary science courses within the STEM education. Procedia-Social and Behavioral Sciences, 177, 223-228. doi: https://doi.org/10.1016/j.sbspro.2015.02.395

[8] Coles, A. (2019). Faciliting the use of video with teachers of mathematics: learning from staying with the detail. International Journal of STEM Education, 6, 1-13. doi: https://doi.org/10.1186/s40594-018-0155-y

[9] Collins, C. S., \& Stockton, C. M. (2018). The central role of theory in qualitative research. International Journal of Qualitative Methods, 17, 1-10. doi: https://doi.org/10.1177/1609406918797475

[10] Connor, A. M., Karmokar, S., Whittington, C. (2015). From STEM to STEAM: strategies for enhancing engineering \& technology education. International Journal of Engineering Pedagogy, 5, 37-47. doi:https://doi.org/10.3991/ijep.v5i2.4 458

[11] Darling-Hammond, L., Flook, L., Cook-Harvey, C., Barron, B., Osher, D. (2019). Implication for educational practice of the science of learning and development. Applied Developmental Science, 1. doi:https://doi.org/10.1080/1088 8691.2018.1537791

[12] English, L. D. (2016). STEM education K-12: perspectives on integration. International Journal of STEM Education, 3, 1-8. doi:https://doi.org/10.1186/s40594-016-0036-1

[13] Ishartono, N., Juniati, D., \& Lukito, A. (2016). Developing Mathematics Teaching Devices in the Topic of Trigonometry Based on Guided Discovery Teaching Method. Journal of Research and Advances in Mathematics Education, 1(2), 154-171.

[14] Jan, H. (2017). Teacher of $21^{\text {st }}$ century: characteristics and development. Research on Humanities and Social Sciences, $7,50-54$.

[15] Kelley, T. R., \& Knowles, J. G. (2016). A conceptual framework for itegrated STEM education. International Journal of STEM Education, 3, 1-11. teacher-facilitated: https://doi.org/10.1186/s40594-016-0046-z

[16] Kemendikbud. (2013). Permendikbud Nomor 70 Tahun 2013 tentang Kerangka Dasar dan Struktur Kurikulum SMK-MAK. Jakarta: Kemendikbud.

[17] Kemendikbud. (2016). Permendikbud Nomor 22 Tahun 2016 tentang Standar Proses Pendidikan dan Menengah. Jakarta: Kemendikbud.

[18] Kinshuk., Chen, N., Cheng, I., \& Chew, S. W. (2016). Evolution is not enough: revolutionizing current learning environments to smart learning environments. International 
Journal of Artificial Intelligence in Education, 26, 561-581. doi:https://doi.org/10.1007/s40593-016-0108-X

[19] Klerk, S. D., Veldkamp, B. P., \& Eggen, T. J. H. M. (2018). A frameork for designing and developing multimedia-based performance assessment in vocational education. Educational Technology Research and Development, 66, 147-171. doi: https://doi.org/10.1007/ s11423-017-9559-5

[20] Li, Y. W. (2016). Transforming conventional teaching classroom to learner-centered teaching classroom using multimedia-mediated learning module. International Journal of Information and Education Technology. doi:https://doi.org/10.7763/IJIET.2016.V6.667

[21] Morrar, R., Arman, H., \& Mousa, S. (2017). The fourth industrial revolution (industry 4.0): a social innovation perspective. Technology Innovation Management Review, 7, $12-20$.

[22] Schipper, T., Goei, S. L., Vries, S. D., Veen, K. V. (2017). Professional growth in adaptive teaching competence as a result of lesson study. Teaching and Teacher Education, 68, 289-303. doi: https://doi.org/10.1016/j.tate.2017.09.015

[23] Serdyukov, P. (2017). Innovation in education: what works, what doesn't, and what to do about it?. Journal of Research in Innovative Teaching \& Learning, 10, 4-33. doi: https://doi.org/10.1108/JRIT-10-2016-0007

[24] Sutama. (2018). Metode Penelitian Pendidikan (Kuantitatif, Kualitatif, PTK, Mix Methods, R\&D). Sukoharjo: CV Jasmine.

[25] Sutama., Anif, S., Prayitno, H. J., \& Sari, D. P. (2019). Metacognitive knowledge of mathematics education students in analytical geometry of space. Journal of Physics: Conf. Series, 1211 012056. doi:https://doi.org/10.1088/174 2-6596/1211/1/012056

[26] Taherdoost, H. (2016). Validiti and reliability of the research instrument; how to test the validation of a questionnaire/survey in a research. International Journal of Academic Research in Management, 5, 28-36.

[27] Wang, K., \& Zhu, C. (2019). MOOC-based flipped learning in higher education: students' participation, experience and learning performance. International Journal of Educational Technology in Higherr Education, 16, 1-18. doi:https://doi.org/10.1186/s41239-019-0163-0

[28] Wilson, J. A., Waghel, R. C., \& Dinkins, M. M. (2019). Flipped classroom versus a didactic method with active learning in a modi fi ed team-based learning self-care pharmacotherapy course. Currents in Pharmacy Teaching and Learning. https://doi.org/10.1016/j.cptl.2019.09.017

[29] Yuniarti, N. N., Susanto., Irvan, M. (2018). The implementation of scientific approach with project based learning model to improve students' analytical skill and respond. International Journal of Advanced Engineering Research and Science, 5, 90-93. doi:https://doi.org/10.2216 1/ijaers.5.10.11

[30] Young, M. (2014). What is a curriculum and what can it do?. The Curriculum Journal, 25, 7-13. doi: https://doi.org/10.1080/09585176.2014.902526

[31] Zhu, L., Lian, Z., \& Engström, M. (2019). Jourl Pre of. Nurse Education Today, 85(February 2020). https://doi.org/10.1016/j.nedt.2019.104262 